\title{
Combined Effect of Hermetic Bag and Insect Resistant Variety for the Control of Larger Grain Borer and Maize Weevil in Stored Maize
}

\author{
Paddy Likhayo $^{\mathrm{b}, \mathrm{c}, *}$, Tadele Tefera ${ }^{\mathrm{a}, 1}$, Stephen Mugo ${ }^{\mathrm{a}}$, Jones Mueke \\ ${ }^{a}$ International Maize and Wheat Improvement Centre (CIMMYT), PO Box 1041 - 00621, Nairobi, Kenya. \\ ${ }^{1}$ Present address: International Centre of Insect Physiology and Ecology (ICIPE), PO Box 5689, Addis Ababa, Ethiopia. \\ ${ }^{\mathrm{b}}$ Kenya Agricultural and Livestock Research Organisation (KALRO), PO Box 14733 - 00800, Nairobi, Kenya. \\ ${ }^{c}$ Kenyatta University (KU), Department of Zoological Sciences, PO Box 43844 - 00100, Nairobi, Kenya.
}

\begin{abstract}
Combined effect of hermetic bag and varietal resistance was studied for control of Prostephanus truncatus and Sitophilus zeamais. Two maize varieties: resistant (CKPH08028) and susceptible (PH3253) were used in combination with SuperGrain bag II PICS bag, Smartbag -1, Polypropylene bag and Actellic super dust. A mean of 5.2\% Carbon dioxide for both PICS and SuperGrain IIT bags and 2.6\% for Smartbag -1 were recorded. PICS and SuperGrain II'M bags suppressed insect population, prevented grain loss and cross - infestation of insects from the surrounding environment. Grain weight losses were $0.3 \%$ in the PICS and $0.9 \%$ in the SuperGrain IV-R ${ }^{\mathrm{TM}}$ bags compared to $23.9 \%$ in the polypropylene bags, 180 days after storage. No grain protection benefits were gained when either insect resistant (CKPH08028) or susceptible (PH5253) maize grains were stored in PICS or SuperGrain IITM bags ( $<5 \%$ damage and $<1 \%$ weight loss). Synergistic benefits in protection were gained when the weight loss of CKPH08028 grains stored in either PICS or SuperGrain II TM bags were compared to that of the same variety stored in the polypropylene bags. Admixture of maize grain with Actellic super dust and storage in polypropylene bag did not prevent infliction of damage (45.6\%) and weight loss (13.6\%) due to insect pests. The novelty of the work is demonstrated in the potential use of hermetic bags in combination with insect resistant maize technologies to significantly reduce weight loss from $30 \%$ to less than $1 \%$ without use of pesticide. This would improve food security at household level. The findings of this study would support agricultural policy formulation and monitoring of loss reduction activities.
\end{abstract}

Keywords: Hermetic bag, insect resistant maize, Prostephanus truncatus, Sitophilus zeamais, weight loss

\section{Introduction}

Maize is an important staple food crop grown widely in subSaharan Africa and a major source of feed, biofuel and industrial raw material (Purseglove 1992). The crop is important socially, politically and economically (McCann et al. 2006). Despite increased production, postharvest losses due to insect and mould infestation remain a big challenge (FAO 2009). During storage maize is prone to attack by field - to -store insect pests among which the majors ones are the maize weevil Sitophilus zeamais (Motsch.) and Angoumois grain moth Sitotroga cerealella (Oliv.) and the introduced invasive larger grain borer Prostephanus truncatus (Horn) (Chebet et al. 2013). Adults of these insects feed on undamaged grains generating flour (dust) rendering the grain unfit for human consumption (Ofuya et al. 2008). Grain damage leads to loss of weight, poor quality and low germination rate (Enobakhare and Law -Ogbomo 2002). In its area of origin in Meso-America and Mexico, P. truncatus was found not to infest maize during storage (Wong - Corral et al. 2001). The infestation of maize grain starts in the field just before harvest and the insects are carried into the store where the population builds up fast (Adedire and Lajide 2003, Hodges et al. 2011).

Traditional storage structures confer unsatisfactory protection against these insect pests in stored grain (Ngamo et al. 2007). The main method for the control of insect pests of stored grain still remains the application of synthetic insecticides. Although insecticides are very effective, there are concerns on their impact on the environment, human health and development of insect resistance (Braga et al. 2011; Ogendo 2004, Pereira et al. 2009). The limited choice of commercially available insecticides, unreliable supply and cost has contributed to low adoption by resource - poor smallholder farmers (Ogendo et al. 2004).

It is estimated that $14-50 \%$ of the maize produced in developing countries is lost during storage (Ojo and Omoloye 2012). To avoid the risk of low quality grain and high grain losses during storage forces smallholder farmers to sell surplus grain immediately after harvest at low prices (Gitonga et al. 2013; Yigesu et al. 2010). The optimal time for selling grain is determined, among other factors, by grain damage and weight losses (Yigesu et al. 2010). While Kenya has for long pursued the goal of self -sufficiency in maize and other crops, majority of rural households are net buyers of maize (Brooks et al. 2009). Food shortage is, therefore, a challenge encountered by resource poor smallholder farmers. Affordable, effective, chemical -free and environmentally friendly control methods are urgently required.

What type of technologies that would reduce grain weight loss from $30 \%$ to less than $3 \%$ is a research question addressed by this study. The target was based on a study by Mutambuki et al. (2011) that reported a 30\% grain weight 


\section{International Journal of Science and Research (IJSR) \\ ISSN (Online): 2319-7064}

Index Copernicus Value (2013): 6.14 | Impact Factor (2014): 5.611

loss in stored maize where no insect pest control intervention was applied. Hermetic bagging and insect resistant maize variety is just such an extension of the 'choice' of technologies available to farmers to explore to lever food security and sustain maize- dependent livelihoods. Hermetic bags are airtight containers which prevent oxygen and water movement between the outside atmosphere and the stored grain or product. The respiration by the grain and insect inside the bags changes inter- granular atmosphere consuming oxygen and producing carbon dioxide (Baoua et al. 2013). Depending on the type of the container and insect population, oxygen levels is reduced (hypoxia) from 21 to below $10 \%$ and carbon dioxide levels increased (hypercarbia) within a short period of time (Mutungi et al. 2014). However, the attainment of high enough carbon dioxide level to kill all the insects in hermetic bags is a challenge. Whereas several studies have examined grain storage infestation under hermetic conditions, little work, however, has been reported on the combined effect of hermetic bagging and insect resistant maize variety. Therefore, the objective of this study was to evaluate the combined effect of hermetic bagging and insect resistant maize against the larger grain borer and maize weevil infestation.

\section{Materials and Method}

\subsection{Study Site}

The studies were carried out at Kenya Agricultural and Livestock Research Organisation (KALRO) - Kiboko in Makueni County. Kiboko lies within $37.7234^{\circ} \mathrm{E}$ and $2.2172^{\circ} \mathrm{S}$ at $975 \mathrm{~m}$ above sea level (CIMMYT 2013). The region is hot and dry with mean annual minimum and maximum temperatures of $16.5^{\circ} \mathrm{C}$ and $28.6^{\circ} \mathrm{C}$, respectively. Maize is among the main crops grown and marketed in the region.

\subsection{Hermetic Bags}

The PICS ${ }^{\circledR}$ and SuperGrain II ${ }^{\mathrm{TM}}$ bags $(74 \mathrm{~cm}$ wide and $64 \mathrm{~cm}$ length) of $90 \mathrm{~kg}$ holding capacity were purchased from the manufacturers' agents in Nairobi. The open end of these bags was cut to fit the height dimension of the conventional farmer bags. As recommended, the hermetic bags were placed inside polypropylene bags to provide support and handling convenience. PICS ${ }^{\circledR}$ and SuperGrain IITM bags are type of multi-layer co-extruded tougher plastics with low permeability in which oxygen is depleted fast.

A newly developed hermetic bag, Smartbag-1, was provided by MashAgrik company of South Africa. It is composed of an outer layer of standard woven polypropylene and inner liner of high density polyethylene (HDPE), 80 microns thick. The hermetic bag had grain - holding capacity of $40 \mathrm{~kg}$.

The polypropylene bags (farmers' traditional storage) of holding capacity of $50 \mathrm{~kg}$ were bought from a local market in Nairobi. Polypropylene bags are made from woven synthetic fibre that is similar to plastic but is more degradable when exposed to sun rays (ACDI/VOCA-Kenya, 2007). The bags somewhat prevent free circulation of air and are difficult to fumigate.

\subsection{Insects}

The insects used in the study were reared at the postharvest laboratory, KALRO, Kiboko. The Prostephanus truncatus (Coleoptera: Bostrichidae) and Sitophilus zeamais (Coleoptera: Curculionidae) cultures were maintained on whole susceptible hybrid $\mathrm{H} 513$ maize variety at $27^{\circ} \mathrm{C}$ and $65 \%$ relative humidity.

\subsection{Sources of resistant and susceptible maize and preparation prior to storage}

Seed for resistance (Maize hybrid CKPH08028) to $P$. truncatus and $S$. zeamais was obtained from the International Centre for Maize and Wheat Improvement Centre (CIMMYT) while the susceptible Hybrid maize variety PH3253 was purchased from the Agrovet at the local market. CKPH08028 maize grain texture is semi - flint with yield estimated at $8.03 \mathrm{t} /$ ha while $\mathrm{PH} 3253$ grain is dent with 7.32 t/ha yield (Mwololo et al. 2013). The two Hybrids were planted at Kiboko research farm for grain increase in mid April 2013 during the long rains season. Two seeds were planted per hill in a row of $5 \mathrm{~m}$ length spaced $75 \mathrm{~cm}$ apart and plant -to -plant distance of $25 \mathrm{~cm}$. Following germination, the plants were thinned to one plant per hill after two weeks to attain a population density of 53,000 plants per hectare. Fertilizer was applied at the recommended rate of $60 \mathrm{~kg} \mathrm{~N}$ and $60 \mathrm{~kg} \mathrm{P}_{2} \mathrm{O}_{5}$ per hectare for Kiboko area. Nitrogen fertilizer was applied twice. The field were kept free of weeds by hand weeding. Water stress was avoided by irrigating the fields. The hybrids were harvested in late August 2013, the cobs sun -dried for seven days then shelled. The moisture content of the maize grain at the start of the storage period was $12.4 \pm 0.0 \%$ for resistant hybrid maize CKPH08028 and $12.3 \pm 0.0$ (wet basis) for the susceptible hybrid PH3253 maize variety while the grain damage for both varieties was $0.6 \pm 0.2 \%$. The grains were not disinfested to kill any insect or eggs present due to random natural infestation in the field.

\subsection{Treatments and Design}

Three hermetic bags and the standard woven polypropylene bag in combination with insect resistant or susceptible hybrid maize were tested for their effectiveness against storage insect pests attack. The experiment comprised of nine treatments: (1) SuperGrain II ${ }^{\mathrm{TM}}$ bag+ resistant maize (SGB + $\mathrm{R})$; (2) SuperGrain II ${ }^{\mathrm{TM}}$ bag + susceptible maize $(\mathrm{SGB}+\mathrm{S})$; (3) PICS bag + resistant maize (PICS + R); (4) PICS bag + susceptible maize (PICS $+\mathrm{S})$; (5) Smartbag-I + resistant maize (SMTB + R); (6) Smartbag-I + susceptible maize $(\mathrm{SMTB}+\mathrm{S})$; (7) Polypropylene bag + resistant maize (PPB $+\mathrm{R})$; (8) Polypropylene bag + susceptible maize $(\mathrm{PPB}+\mathrm{S})$ and (9) Polypropylene bag + susceptible maize + Actellic super dust $(\mathrm{PPB}+\mathrm{S}+\mathrm{A})$. A completely randomised design was used where the level of factors were 8 treatments and two storage periods. The containers were placed in a room described by DeGroote et al. (2013) at Kiboko in four rows, with $0.5 \mathrm{~m}$ distance between the rows and $0.3 \mathrm{~m}$ within the 


\section{International Journal of Science and Research (IJSR) \\ ISSN (Online): 2319-7064}

Index Copernicus Value (2013): 6.14 | Impact Factor (2014): 5.611

rows. All the treatments were held under ambient conditions. The temperature was recorded on a daily basis.

\subsubsection{Grain Bagging and Storage}

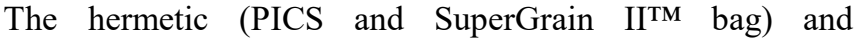
polypropylene bags were filled with $30 \mathrm{~kg}$ grains each of Hybrid maize variety CKPH08028. Similar preparation was made for susceptible Hybrid PH3253. Polypropylene bag filled with susceptible Hybrid PH3253 maize served as a control. The bags were artificially infested with adult larger grain borer and maize weevil at the rate of 1 adult beetles $/ \mathrm{kg}$ grains (15 P. truncatus $+15 \mathrm{~S}$. zeamais) at the top centre of the grains. The bags were stored at ambient conditions in a shaded barn for six months' period. The entrapped air was squeezed out and then the bags secured tightly with rubber straps. according to manufacturer's instructions. The treatments were arranged in a completely randomised design with four replications. The bags were held on wooden pallets in four rows in the barn with open wire mesh and concrete walls at ambient conditions. The pallets were placed about $0.3 \mathrm{~m}$ between and $0.2 \mathrm{~m}$ within the rows

Oxygen, carbon dioxide and temperature levels inside PICS bag, Smartbag -1 and SuperGrain II ${ }^{\mathrm{TM}}$ bag were measured at 10 - day intervals using Mocon Pack Check ${ }^{\circledR}$ Model 325 portable oxygen/carbon dioxide headspace analyser (MOCON Inc., Minneapolis, USA). The analyser is fitted with sensors and automatic internal air sampling pump. To facilitate taking of measurements, the inner HDPE liner was pierced with the analyser needle near the top to draw $5 \mathrm{~mL}$ of air for determining oxygen, carbon dioxide and temperature. Oxygen and carbon dioxide levels determined by electrochemical cell and non - dispersive infrared methods, respectively. The needle holes were then plugged with circular adhesive pads (10 $\mathrm{mm}$ diameter) immediately after taking the readings. The mean of the three 10-day readings in a month was then recorded as 30-day reading. Subsequent readings were taken from the same spot by unsealing and re-sealing with the adhesive pad and reenforced by wind tape.

\subsubsection{Grain Sampling and Damage Analysis}

Samples were drawn non - destructively at 90 and 180 days after the setup, respectively, using a vertical sampling 6 -slot spear (probe) with special care taken not to pierce the bags. Repeated sampling from the same storage structure reflects farmer practices of opening the structures at regular interval to draw grain for use as household food. At each sampling time, the bags are unsealed, grains drawn from the centre and two peripheral points then the bags resealed again. The grains from these three points were bulked and the whole lot (about 450g) per replicate of each treatment used as a working sample. Each sample was put in a clean labelled zip-lock $(8 \times 6 \mathrm{~cm})$ plastic bag for subsequent insect damage analysis in the laboratory. In the laboratory, a set of sieves (4.75 and $1.0 \mathrm{~mm}$ aperture size) were used to separate the insects from the grains. After sieving the samples, a half of each grain sample was obtained by use of riffle divider and sorted out into undamaged and damaged grain fractions. A grain was regarded damaged when its surface showed the presence of holes or tunnels made by insect's emergence or feeding activities while undamaged showed none. The number and weights of each fraction were recorded. Grain damage and weight loss was calculated as follows:

$$
\begin{aligned}
& \text { Grain damage }(\%)=\frac{\text { Number of insect damaged grain }}{\text { Total number of grain }} \times 100 \\
& \text { Weight loss }(\%)=100 \times \frac{\left(\mathrm{W}_{\mathrm{s}} \times \mathrm{N}_{d}\right)-\left(\mathrm{W}_{d} \times \mathrm{N}_{\mathrm{g}}\right)}{\mathrm{W}_{\mathrm{s}} \times\left(\mathrm{N}_{\mathrm{s}}+\mathrm{N}_{\mathrm{d}}\right)} \text { (Boxall, 1986) }
\end{aligned}
$$

Where $\mathrm{W}_{\mathrm{u}}$ and $\mathrm{W}_{\mathrm{d}}$ is the weight of undamaged and damaged grain, respectively; $\mathrm{N}_{\mathrm{u}}$ and $\mathrm{N}_{\mathrm{d}}$ is the number of undamaged and damaged grain, respectively.

The hermetic bag and polypropylene bags were inspected for the presence of holes made by $P$. truncatus during storage at termination time.

\subsection{Data Analysis}

The data were subjected to analysis of variance (ANOVA). Insect count data were transformed to $\log _{10}(\operatorname{count}+1)$ scale while percentage oxygen, carbon dioxide, , grain damage and weight loss data were square root transformed prior to statistical analysis. The general linear model (GLM) procedure of GenStat software release 12.1 for windows (VSN International Ltd, 2009) was used for all the analysis. The treatments and storage period were the main effects. The associated interactions of the main effects were included in the analysis. Significant differences were separated using Bonferroni test at 0.05 probability.

\section{Results}

The moisture content of the maize grain at the start of the storage period was $12.4 \pm 0.0 \%$ for resistant hybrid maize CKPH08028 and $12.3 \pm 0.0$ (wet basis) susceptible hybrid $\mathrm{PH} 3253$ while the grain damage for both varieties was $0.6 \pm$ $0.2 \%$.

\subsection{Temperature, oxygen and carbon dioxide levels}

Temperature levels changed significantly with storage period $\left(\mathrm{F}_{6,123}=40.49 ; \mathrm{P}<0.001\right)$ but not with treatment $(\mathrm{P}=0.318)$ (Figure 1). There were no significant interaction differences between hermetic treatments and storage period was detected $(\mathrm{P}=0.767)$. Overall, the temperature levels changed over the course of the storage duration but remained relatively high at $28-32^{\circ} \mathrm{C}$. This corresponds to the typical hot weather that prevails at Kiboko before the onset of short rains which starts in October and ends in February.

There were significant differences between treatment, storage time and treatment by storage interaction in affecting oxygen and carbon dioxide levels (Table 1). No significant differences between treatments in level of oxygen and carbon dioxide at the onset of the treatments (zero days) was observed (Table 2); however, significant differences were observed 30 days after treatment application. The level of oxygen drastically dropped in PICS bag followed by SuperGrain II TM bag; however, there was a gradual decline in oxygen in Smartbag-I during the storage period (Table 2). There was high concentration of carbon dioxide in SuperGrain II ${ }^{\mathrm{TM}}$ bag between 30 and 120 days after treatment application followed by PICS bag; nevertheless,

\section{Volume 4 Issue 12, December 2015}




\section{International Journal of Science and Research (IJSR) \\ ISSN (Online): 2319-7064 \\ Index Copernicus Value (2013): 6.14 | Impact Factor (2014): 5.611}

the interaction showed that the highest concentration of carbon dioxide was recorded from PICS bag 150 days after least concentration of carbon dioxide throughout the storage treatment application (Table 2). Smartbag-I sustained the period.

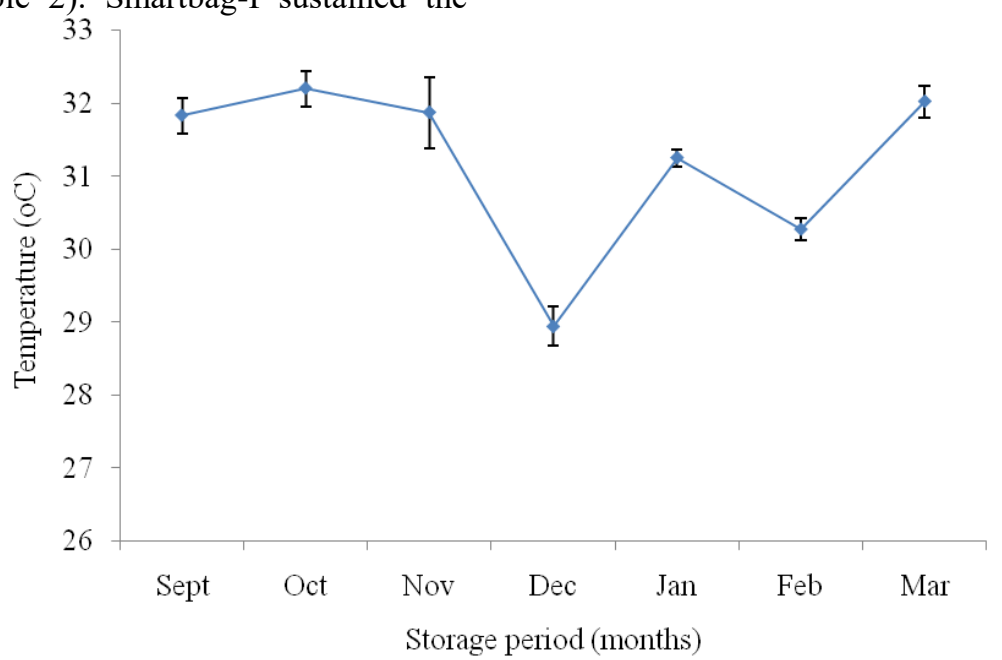

Figure 1: Mean temperature of the hybrid maize grains stored in hermetic bags over six months storage duration.

Table 1: Factorial analyses of the effect of treatment and storage period on changes in oxygen and carbon dioxide levels

\begin{tabular}{|c|c|c|c|c|}
\hline Factor & Mean Square & $F$ & $d . f$ & $P$-value \\
\hline Oxygen level & & & & \\
\hline Treatment & 4.357 & 587.38 & 5 & $<0.001$ \\
\hline Storage period & 2.236 & 301.38 & 6 & $<0.001$ \\
\hline Treatment x Storage period & 0.186 & 25.06 & 30 & $<0.001$ \\
\hline Residual & 0.007 & & 123 & \\
\hline & & & & \\
\hline Carbon dioxide level & & & & \\
\hline Treatment & 2.958 & 136.90 & 5 & $<0.001$ \\
\hline Storage period & 6.493 & 300.50 & 6 & $<0.001$ \\
\hline Treatment x Storage period & 0.372 & 17.22 & 30 & $<0.001$ \\
\hline Residual & 0.022 & & 123 & \\
\hline
\end{tabular}

Table 2: Effect of the treatment and storage period interactions on changes in oxygen and carbon dioxide levels in the hermetic bags $\left(\operatorname{mean}^{1} \pm \mathrm{SE}\right)$

\begin{tabular}{|c|c|c|c|c|c|c|c|c|}
\hline \multirow[t]{2}{*}{ Treatment } & \multicolumn{7}{|c|}{ Storage period (days) } & \multirow[b]{2}{*}{ Mean $^{2}$} \\
\hline & 0 & 30 & 60 & 90 & 120 & 150 & 180 & \\
\hline \multicolumn{9}{|c|}{ Oxygen level (\%) } \\
\hline $\mathrm{SGB}+\mathrm{R}$ & $20.3 \pm 0.0 \mathrm{mn}$ & $.4 \pm 0.1 \mathrm{fg}$ & $15.1 \pm 0.5 \mathrm{~g}-\mathrm{i}$ & $16.0 \pm 0.5 \mathrm{~h}-\mathrm{j}$ & $16.0 \pm 0.0 \mathrm{~h}-\mathrm{j}$ & $15.9 \pm 0.2 \mathrm{~h}-\mathrm{j}$ & $15.5 \pm 0.2 \mathrm{hi}$ & $16.0 \mathrm{~d}$ \\
\hline $\mathrm{SGB}+\mathrm{S}$ & $20.4 \pm 0.1 \mathrm{mn}$ & $12.1 \pm 0.2 \mathrm{ef}$ & $15.5 \pm 0.1 \mathrm{hi}$ & $14.6 \pm 0.6 \mathrm{gh}$ & $14.5 \pm 0.3 \mathrm{gh}$ & $16.0 \pm 0.3 \mathrm{~h}-\mathrm{j}$ & $15.1 \pm 0.2 \mathrm{~g}-\mathrm{i}$ & $15.5 \mathrm{c}$ \\
\hline $\mathrm{PICS}+\mathrm{R}$ & $20.3 \pm 0.1 \mathrm{mn}$ & $9.4 \pm 0.0 \mathrm{a}-\mathrm{c}$ & $11.1 \pm 0.1 \mathrm{de}$ & $8.9 \pm 0.7 \mathrm{ab}$ & $8.2 \pm 0.3 \mathrm{ab}$ & $12.0 \pm 0.5 \mathrm{ef}$ & $11.4 \pm 0.2 \mathrm{de}$ & $11.6 \mathrm{a}$ \\
\hline $\mathrm{PICS}+\mathrm{S}$ & $20.4 \pm 0.0 \mathrm{mn}$ & $9.0 \pm 0.3 \mathrm{ab}$ & $12.4 \pm 0.3 \mathrm{ef}$ & $9.2 \pm 0.7 \mathrm{ab}$ & $10.9 \pm 0.4 \mathrm{c}-\mathrm{e}$ & $13.3 \pm 0.2 \mathrm{fg}$ & $10.1 \pm 0.2 \mathrm{~b}-\mathrm{d}$ & $12.2 \mathrm{~b}$ \\
\hline SMTB + R & $20.4 \pm 0.1 \mathrm{n}$ & $18.4 \pm 0.2 \mathrm{k}-\mathrm{n}$ & $18.3 \pm 0.1 \mathrm{k}-\mathrm{n}$ & $17.6 \pm 0.2 \mathrm{j}-1$ & $18.2 \pm 0.1 \mathrm{k}-\mathrm{m}$ & $18.9 \pm 0.11-n$ & $19.3 \pm 0.31-n$ & $18.7 \mathrm{f}$ \\
\hline SMTB + S & $20.5 \pm 0.0 \mathrm{n}$ & $16.7 \pm 0.2 \mathrm{i}-\mathrm{k}$ & $16.4 \pm 0.2 \mathrm{~h}-\mathrm{k}$ & $16.7 \pm 0.4 \mathrm{i}-\mathrm{k}$ & $16.5 \pm 0.2 \mathrm{~h}-\mathrm{k}$ & $19.0 \pm 0.31-n$ & $19.6 \pm 0.11-n$ & $17.9 \mathrm{e}$ \\
\hline Mean $^{2}$ & $4 \mathrm{e}$ & $13.2 \mathrm{a}$ & $14.8 \mathrm{~b}$ & $13.8 \mathrm{~b}$ & $14.0 \mathrm{c}$ & $15.9 \mathrm{~d}$ & $15.2 \mathrm{~d}$ & \\
\hline \multicolumn{9}{|c|}{ Carbon dioxide (\%) } \\
\hline $\mathrm{SGB}+\mathrm{R}$ & $0.8 \pm 0.1 \mathrm{ab}$ & $6.7 \pm 0.5 \mathrm{~m}-\mathrm{p}$ & $5.3 \pm 0.3 \mathrm{i}-\mathrm{o}$ & $5.2 \pm 0.5 \mathrm{i}-\mathrm{o}$ & $5.1 \pm 0.1 \mathrm{i}-\mathrm{n}$ & $5.6 \pm 0.3 \mathrm{k}-\mathrm{o}$ & $5.4 \pm 0.2 \mathrm{j}-\mathrm{o}$ & $4.9 \mathrm{c}$ \\
\hline $\mathrm{SGB}+\mathrm{S}$ & $\pm 0.1 \mathrm{a}$ & $6.9 \pm 0.1 \mathrm{n}-\mathrm{p}$ & $5.4 \pm 0.2 \mathrm{j}-\mathrm{o}$ & $6.6 \pm 0.71-p$ & $6.6 \pm 0.31-p$ & $6.4 \pm 0.81-\mathrm{p}$ & $6.5 \pm 0.41-p$ & $5.6 \mathrm{~d}$ \\
\hline $\mathrm{PICS}+\mathrm{R}$ & $0.8 \pm 0.0 \mathrm{a}$ & $5.1 \pm 0.1 \mathrm{i}-\mathrm{n}$ & $3.5 \pm 0.2 \mathrm{e}-\mathrm{i}$ & $5.3 \pm 0.4 \mathrm{j}-\mathrm{o}$ & $6.4 \pm 0.71-\mathrm{p}$ & $7.4 \pm 0.7 \mathrm{o}-\mathrm{q}$ & $8.6 \pm 0.1 \mathrm{pq}$ & $5.3 \mathrm{~cd}$ \\
\hline $\mathrm{PICS}+\mathrm{S}$ & $0.7 \pm 0.0 \mathrm{a}$ & $5.3 \pm 0.0 \mathrm{j}-\mathrm{o}$ & $3.1 \pm 0.3 \mathrm{e}-\mathrm{h}$ & $5.0 \pm 0.4 \mathrm{i}-\mathrm{n}$ & $4.8 \pm 0.3 \mathrm{~h}-\mathrm{m}$ & $6.5 \pm 0.11-p$ & $9.7 \pm 0.4 q$ & $5.0 \mathrm{c}$ \\
\hline $\mathrm{SMTB}+\mathrm{R}$ & $0.6 \pm 0.0 \mathrm{a}$ & $2.9 \pm 0.4 \mathrm{~d}-\mathrm{f}$ & $2.7 \pm 0.1 \mathrm{c}-\mathrm{f}$ & $3.6 \pm 0.2 \mathrm{e}-\mathrm{j}$ & $2.9 \pm 0.1 \mathrm{~d}-\mathrm{g}$ & $2.2 \pm 0.1 \mathrm{c}-\mathrm{e}$ & $1.6 \pm 0.3 \mathrm{bc}$ & $2.4 \mathrm{a}$ \\
\hline SMTB + S & $0.6 \pm 0.0 \mathrm{a}$ & $2.9 \pm 0.1 \mathrm{~d}-\mathrm{f}$ & $3.9 \pm 0.2 \mathrm{f}-\mathrm{k}$ & $4.6 \pm 0.3 \mathrm{~g}-1$ & $4.6 \pm 0.2 \mathrm{~h}-1$ & $2.7 \pm 0.3 \mathrm{c}-\mathrm{f}$ & $1.7 \pm 0.2 b c$ & $3.0 \mathrm{~b}$ \\
\hline Mean $^{2}$ & $0.7 \mathrm{a}$ & $5.0 \mathrm{c}$ & $4.0 \mathrm{~b}$ & $5.1 \mathrm{c}$ & $5.1 \mathrm{c}$ & $5.1 \mathrm{c}$ & $5.6 \mathrm{c}$ & \\
\hline
\end{tabular}

Where $\mathrm{SGB}+\mathrm{R}=$ SuperGrain $\mathrm{II}^{\mathrm{TM}}$ bag + resistant maize, $\mathrm{SGB}+\mathrm{S}=$ SuperGrain II ${ }^{\mathrm{TM}}$ bag + susceptible maize, PICS + $\mathrm{R}=\mathrm{PICS}$ bag + resistant maize,
$\mathrm{PICS}+\mathrm{S}=\mathrm{PICS}$ bag + susceptible maize, $\mathrm{SMTB}+\mathrm{R}=$ Smartbag $-1+$ resistant maize and SMTB $+\mathrm{S}=$ Smartbag -1 + susceptible maize. 


\section{International Journal of Science and Research (IJSR) \\ ISSN (Online): 2319-7064 \\ Index Copernicus Value (2013): 6.14 | Impact Factor (2014): 5.611}

${ }^{1}$ Means within the same column and row followed by the same letter are not significantly different at $\mathrm{P}=0.05$ level. ${ }^{2}$ Means of the main treatment effects followed by the same letter are not significantly different at $\mathrm{P}=0.05$ level.

\subsection{Number of adult $P$. truncatus and $S$. zeamais}

There were significant differences between treatment, storage time and treatment by storage interaction in affecting the number of insects (Table 3). The least number of both insects was recorded when the susceptible (PH3253) or resistant (CKP08028) maize hybrids were stored in PICS bags (Table 4). Grains stored in Smartbag-I harboured large number of $P$. truncatus than SuperGrain II TM $^{\text {bag. The }}$ susceptible hybrid (PH3253) stored in polypropylene bag treated with Actellic dust had the highest number of $P$. truncatus than S. zeamais. Both susceptible (PH3253) and resistant (CKP08028) maize hybrids had the highest number of $S$. zeamais when stored in polypropylene bag.
Table 3: Factorial analyses of the effect of treatment and storage duration on the number of Prostephanus truncatus and Sitophilus zeamais in grain samples.

\begin{tabular}{|c|c|c|c|c|}
\hline Factor & $\begin{array}{c}\text { Mean } \\
\text { Square }\end{array}$ & $F$ & $d . f$ & $P$-value \\
\hline No. of P. truncatus & & & & \\
\hline Treatment & 2.359 & 23.31 & 8 & $<0.001$ \\
\hline Storage period & 14.655 & 144.84 & 1 & $<0.001$ \\
\hline Treatment x Storage period & 0.861 & 8.51 & 8 & $<0.001$ \\
\hline Residual & 0.101 & & 51 & \\
\hline & & & & \\
\hline No. of S. zeamais & & & & \\
\hline Treatment & 9.334 & 5.19 & 8 & $<0.001$ \\
\hline Storage period & 211.400 & 117.43 & 1 & $<0.001$ \\
\hline Treatment x Storage period & 3.722 & 2.07 & 8 & 0.057 \\
\hline Residual & 1.800 & & 51 & \\
\hline
\end{tabular}

Table 4: The effect of treatment and storage period interaction on the mean ${ }^{1}$ number of Prostephanus truncatus $( \pm \mathrm{SE})$ and Sitophilus zeamais $( \pm \mathrm{SE})$ in grain samples

\begin{tabular}{|c|c|c|c|c|c|c|}
\hline \multirow[t]{3}{*}{ Treatment } & \multirow{2}{*}{\multicolumn{2}{|c|}{$\begin{array}{c}\text { No. of P. truncatus } \\
\text { Storage period (days) }\end{array}$}} & \multirow{2}{*}{\multicolumn{4}{|c|}{$\begin{array}{c}\text { No. of S. zeamais } \\
\text { Storage period (days) }\end{array}$}} \\
\hline & & & & & & \\
\hline & 90 & 180 & Mean $^{2}$ & 90 & 180 & Mean $^{2}$ \\
\hline SuperGrain II TM bag + CKPH08028 & $1 \pm 1 \mathrm{ab}$ & $9 \pm 4 a b c$ & $5 \mathrm{ab}$ & $1 \pm 0 \mathrm{a}$ & $32 \pm 8$ bcde & $17 \mathrm{ab}$ \\
\hline SuperGrain II ${ }^{\mathrm{TM}}$ bag + PH3253 & $0 \pm 0 \mathrm{a}$ & $8 \pm 5 \mathrm{abc}$ & $4 a b$ & $0 \pm 0 \mathrm{a}$ & $36 \pm 14 \mathrm{bcde}$ & $18 \mathrm{ab}$ \\
\hline PICS bag + CKPH08028 & $0 \pm 0 \mathrm{a}$ & $1 \pm 0 \mathrm{ab}$ & $1 \mathrm{a}$ & $0 \pm 0 \mathrm{a}$ & $9 \pm 2 \mathrm{abc}$ & $5 \mathrm{a}$ \\
\hline PICS bag + PH3253 & $1 \pm 1 \mathrm{ab}$ & $1 \pm 1 \mathrm{ab}$ & $1 \mathrm{a}$ & $0 \pm 0 \mathrm{a}$ & $10 \pm 4 a b c$ & $5 \mathrm{a}$ \\
\hline Smartbag -1 + CKPH08028 & $2 \pm 1 \mathrm{ab}$ & $96 \pm 31 \mathrm{de}$ & $49 \mathrm{~cd}$ & $4 \pm 1 \mathrm{ab}$ & $12 \pm 5 \mathrm{abcd}$ & $8 \mathrm{a}$ \\
\hline Smartbag -1 + PH3253 & $4 \pm 3 \mathrm{abc}$ & $187 \pm 48 \mathrm{e}$ & $95 \mathrm{de}$ & $4 \pm 1 \mathrm{ab}$ & $43 \pm 12$ cde & $23 \mathrm{bc}$ \\
\hline Polypropylene bag + CKPH08028 & $5 \pm 3 a b c$ & $22 \pm 7 \mathrm{~cd}$ & $13 \mathrm{bcd}$ & $2 \pm 1 \mathrm{a}$ & $52 \pm 18 \mathrm{de}$ & $27 \mathrm{ab}$ \\
\hline Polypropylene bag + PH3253 & $1 \pm 1 \mathrm{a}$ & $17 \pm 4 \mathrm{~cd}$ & $9 \mathrm{abc}$ & $8 \pm 2 \mathrm{abc}$ & $57 \pm 17 \mathrm{e}$ & $32 b$ \\
\hline Polypropylene bag +Actellic + PH3253 & $10 \pm 2 b c$ & $407 \pm 41 \mathrm{e}$ & $209 \mathrm{e}$ & $0 \pm 0 \mathrm{a}$ & $15 \pm 5$ abcde & $7 \mathrm{ab}$ \\
\hline Mean $^{2}$ & $3 a$ & $83 \mathrm{~b}$ & & $2 \mathrm{a}$ & $29 \mathrm{~b}$ & \\
\hline
\end{tabular}

${ }^{1}$ Means within the same column and row followed by the same letter are not significantly different at $\mathrm{P}=0.05$ level. ${ }^{2}$ Means of the main treatment effects followed by the same letter are not significantly different at $\mathrm{P}=0.05$ level.

\subsection{Grain Damage and Weight Loss}

There were significant differences between treatments, storage time and interaction between treatment and storage time in grain damage and weight loss (Tables 5 and 6). SuperGrain II ${ }^{\mathrm{TM}}$ bag and PICS bags were the safest storage structures in protecting grains against $P$. truncatus and $S$. zeamais with less than $5 \%$ grain damage and less than $1 \%$ weight loss 180 days after storage, irrespective; both in susceptible and resistant maize (Table 6). Grains of both the susceptible (PH3253) and resistant (CKP08028) hybrids stored in Smartbag-1 bags had the highest damage (49\%) and weight loss $(15 \%)$ followed by grains stored in polypropylene bags treated with Actellic super dust. Some level of grain protection against the $P$. truncatus and $S$. zeamais was observed when either of Smartbag-1 bag $(22 \%$ weight loss) or polypropylene bag (17.4\% weight loss) was combined with the resistant maize (CKPH08028) after 180 days of storage (Table 6) compared to susceptible PH3253 maize variety. A significant increase in grain damage and loss was observed with an increase in storage time in different treatments but not in PICS bags.

Table 5: Factorial analyses of the effect of treatment and storage duration on damage and weight loss caused by storage insect pests

\begin{tabular}{|c|c|c|c|c|}
\hline Factor & $\begin{array}{c}\text { Mean } \\
\text { Square }\end{array}$ & $F$ & d.f & P-value \\
\hline Grain damage (\%) & & & & \\
\hline Treatment & 38.483 & 1027.23 & 8 & $<0.001$ \\
\hline Storage period & 243.728 & 6505.93 & 1 & $<0.001$ \\
\hline Treatment x Storage period & 15.842 & 422.89 & 8 & $<0.001$ \\
\hline Residual & 0.037 & & 51 & \\
\hline & & & & \\
\hline Weight loss (\%) & & & & \\
\hline Treatment & 12.350 & 693.15 & 8 & $<0.001$ \\
\hline Storage period & 94.458 & 5301.58 & 1 & $<0.001$ \\
\hline Treatment x Storage period & 7.332 & 411.50 & 8 & $<0.001$ \\
\hline Residual & 0.018 & & 51 & \\
\hline
\end{tabular}




\section{International Journal of Science and Research (IJSR) \\ ISSN (Online): 2319-7064}

Index Copernicus Value (2013): 6.14 | Impact Factor (2014): 5.611

Table 6: The effect of the treatment and storage period interactions on the mean ${ }^{1}$ percentage grain damage $( \pm$ SE) and weight loss $( \pm \mathrm{SE})$ caused by storage insect pest infestation

\begin{tabular}{|c|c|c|c|c|c|c|}
\hline \multirow{2}{*}{ Treatment } & \multicolumn{3}{|c|}{ Grain damage (\%) } & \multicolumn{3}{c|}{ Weight loss (\%) } \\
\cline { 2 - 7 } & \multicolumn{3}{|c|}{ Storage period (days) } & \multicolumn{3}{c|}{ Storage period (days) } \\
\cline { 2 - 6 } & 90 & 180 & Mean $^{2}$ & 90 & 180 & Mean $^{2}$ \\
\hline SuperGrain II ${ }^{\mathrm{TM}}$ bag + CKPH08028 & $1.0 \pm 0.1 \mathrm{a}$ & $7.0 \pm 0.4 \mathrm{~b}$ & $4.0 \mathrm{~b}$ & $0.2 \pm 0.0 \mathrm{a}$ & $0.9 \pm 0.2 \mathrm{~cd}$ & $0.5 \mathrm{bc}$ \\
\hline SuperGrain II ${ }^{\mathrm{TM}}$ bag + PH3253 & $1.2 \pm 0.1 \mathrm{a}$ & $7.7 \pm 0.6 \mathrm{~b}$ & $4.5 \mathrm{~b}$ & $0.4 \pm 0.1 \mathrm{abc}$ & $0.9 \pm 0.1 \mathrm{~d}$ & $0.6 \mathrm{c}$ \\
\hline PICS bag + CKPH08028 & $1.1 \pm 0.1 \mathrm{a}$ & $1.6 \pm 0.2 \mathrm{a}$ & $1.3 \mathrm{a}$ & $0.1 \pm 0.0 \mathrm{a}$ & $0.3 \pm 0.1 \mathrm{ab}$ & $0.2 \mathrm{a}$ \\
\hline PICS bag + PH3253 & $1.7 \pm 0.1 \mathrm{a}$ & $1.5 \pm 0.1 \mathrm{a}$ & $1.6 \mathrm{a}$ & $0.2 \pm 0.0 \mathrm{a}$ & $0.3 \pm 0.0 \mathrm{ab}$ & $0.2 \mathrm{a}$ \\
\hline Smartbag -1 + CKPH08028 & $6.3 \pm 0.3 \mathrm{~b}$ & $77.1 \pm 5.1 \mathrm{de}$ & $41.7 \mathrm{de}$ & $0.9 \pm 0.1 \mathrm{~d}$ & $22.0 \pm 1.1 \mathrm{f}$ & $11.5 \mathrm{~d}$ \\
\hline Smartbag -1 + PH3253 & $8.5 \pm 0.3 \mathrm{~b}$ & $89.9 \pm 0.7 \mathrm{f}$ & $49.2 \mathrm{f}$ & $1.3 \pm 0.2 \mathrm{~d}$ & $28.8 \pm 0.9 \mathrm{~h}$ & $15.0 \mathrm{f}$ \\
\hline Polypropylene bag + CKPH08028 & $6.9 \pm 0.6 \mathrm{~b}$ & $49.1 \pm 1.5 \mathrm{c}$ & $28.0 \mathrm{c}$ & $1.1 \pm 0.1 \mathrm{~d}$ & $17.4 \pm 0.5 \mathrm{e}$ & $9.2 \mathrm{~d}$ \\
\hline Polypropylene bag + PH3253 & $6.0 \pm 0.3 \mathrm{~b}$ & $73.2 \pm 0.2 \mathrm{~d}$ & $39.6 \mathrm{~d}$ & $0.6 \pm 0.0 \mathrm{bcd}$ & $23.9 \pm 0.4 \mathrm{fg}$ & $12.3 \mathrm{de}$ \\
\hline Polypropylene bag +Actellic + PH3253 & $7.5 \pm 0.3 \mathrm{~b}$ & $83.8 \pm 1.2 \mathrm{ef}$ & $45.6 \mathrm{f}$ & $1.0 \pm 0.1 \mathrm{~d}$ & $26.3 \pm 0.7 \mathrm{~h}$ & $13.6 \mathrm{ef}$ \\
\hline Mean $^{2}$ & $4.5 \mathrm{a}$ & $43.4 \mathrm{~b}$ & 24.0 & $0.6 \mathrm{a}$ & $13.4 \mathrm{~b}$ & 7.0 \\
\hline
\end{tabular}

${ }^{1}$ Means within the same column and row followed by the same letter are not significantly different at $\mathrm{P}=0.05$ level

${ }^{2}$ Means of the main treatment effects followed by the same letter are not significantly different at $\mathrm{P}=0.05$ level

\section{Discussion}

The temperature regime of the grain affects to a great extent the rate of metabolism, growth, development and insect population level (Girish 1965). Higher temperature results in greater insect activity. Temperature regime that favours most insect pests of stored grain is reported to be between $25^{\circ} \mathrm{C}$ and $30^{\circ} \mathrm{C}$ (Hayma 2003). In this study, the temperature in the bags environment was high enough to favour grain damage by the insects, their growth and reproduction.

It is evident that oxygen depletion and carbon dioxide evolution in the current study did not reach extreme levels. This could be attributed probably to bag perforation made by $P$. truncatus and insufficient respiration and metabolism of insects and grain itself. The decline in oxygen and increase in carbon dioxide levels is dependent on air-tightness of the storage structure, insect population, grain moisture content, grain quality and fungi load. Low grain moisture content and insect population in the absence of fungi lead to low oxygen demand in the bags (Moreno-Martinéz et al. 2000). Probably the dry grain in the present study coupled with low insect population and bag perforation prevented creation of depleted oxygen and enriched carbon dioxide environment. The survival of a few insects did seem to increase progeny production in grains stored in hermetic bags. Although there were significant differences in oxygen levels with hermetic treatments, the levels in SuperGrain II ${ }^{\mathrm{TM}}$ bag and Smartbag-I were sufficiently high to support the survival of $P$. truncatus and S. zeamais. Apart from Smartbag-I and polypropylene bag treated with Actellic dust, the rest of the treatments recorded more $S$. zeamais than $P$. truncatus. It is not clear whether $S$. zeamais has the capacity to switch to anaerobic metabolism as an adaptation to hypoxic environment. Extreme oxygen reduction attainment failure under hermetic conditions has been reported in clean grain stored without pre-storage insect and fungal attack (Moreno-Martinéz et al. $2000)$ and in maize grain infested with or without $P$. truncatus (Njoroge et al. 2014). In Njoroge et al. (2014) work, the build up of carbon dioxide on average stabilised at $13.8 \%$ in grain stored in PICS bag over six months storage. Carbon dioxide averaged 5.2\% for both SuperGrain II ${ }^{\mathrm{TM}}$ and PICS bags and $2.6 \%$ of Smartbag -1 bag in the current study.
Grain damage and weight loss of maize stored in of Smartbag -1 and polypropylene bags was economically significant at 180 days storage period. On average, grain damage and weight loss of $83.5 \%$ and $25.4 \%$ was recorded in Smartbag -1 whilst $61.1 \%$ and $20.7 \%$, was from polypropylene bag. PICS bag maintained maize with no visible grain damage and weight loss over the entire storage duration. The finding of this study is in concordance with $0.3 \%$ weight loss reported by Hell et al. (2010) over same storage duration. Although extreme levels of oxygen and carbon dioxide were not attained, the low damage and weight loss levels observed indicated that the insects were inactive. Very low oxygen level has been shown to change fecundity and delay development without causing mortality of the insects while elevated carbon dioxide level in some insects may induce diapauses (Bailey and Banks, 1980). The study demonstrates that even with infested grain before

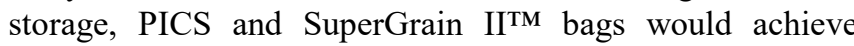
satisfactory protection against damage and weight loss. On termination of the study, Smartbag -1 and polypropylene bags and maize stored therein were heavily holed/damaged.

Admixture of maize grain with Actellic super dust and storage in polypropylene bag did not prevent infliction of damage and weight due to insect pests. Loss of grain protectants' biological activity depends on factors such ambient temperature. Higher temperatures generally lead to greater rates of decay of protectant efficacy (Athanassiou $e t$ al., 2008). The influence of higher safe level of temperature is shown by reduced efficacy (Samson et al., 1988). Whereas the insecticidal potency of Actellic Super dust ${ }^{\circledR}$ has been shown to reduce with time (Denloye et al., 2008), the inadequate control of $P$. truncatus and $S$. zeamais could not be attributed to the ambient temperatures. Dilute contact insecticide such as Actellic Super dust is usually admixed with grains as a preventive strategy on the storage day. However, even with proper admixture a portion of grains remains uncovered resulting in partial treatment (Vassilakos and Athanassiou et al., 2012). Whereas S. zeamais would be controlled when exposed to partially treated grain, $P$. truncatus exhibit some degree of tolerance. This may explain the high number of $P$. truncatus recorded in the current study. Although the two species occur together in storage, it has been predicted that $P$. truncatus dominates the 


\section{International Journal of Science and Research (IJSR) \\ ISSN (Online): 2319-7064}

Index Copernicus Value (2013): 6.14 | Impact Factor (2014): 5.611

interaction with $S$. zeamais at temperatures greater than $28^{\circ} \mathrm{C}$ (Howard 1983). P. truncatus competitive performance is higher in the presence of flour, which is generated by its feeding activities, mixed with whole grain. Since the average temperature in the hermetic bags was above $30^{\circ} \mathrm{C}$ (Figure 1), it is likely that $P$. truncatus outcompeted $S$. zeamais at such temperature. This observation confirms the prediction by Howard (1983).

While smallholder famers rely greatly on maize production and marketing as source of food supply and income, use of hermetic storage and insect resistant maize technologies would play an important role in ensuring constant supply of the staple food grain in many households. The current study examined the combined effect of hermetic bag and insect resistant maize to establish if some benefits would be gained in grain protection against $P$. truncatus and $S$. zeamais in stored maize. Grain weight loss is the most important criterion used to classify maize into either resistant or susceptible varieties (Derera et al., 2014; Mwololo et al., 2012). The treatment combination showed that storing either resistant (CKPH08028) or susceptible maize (PH3253) in hermetic PICS or SuperGrain II ${ }^{\mathrm{TM}}$ bags under same conditions had similar protection as indicated by the percentage grain weight loss except for Smartbag -1 and polypropylene bags after 180 days of storage. Although the oxygen levels were sufficiently high in both SuperGrain II ${ }^{\text {TM }}$ and Smartbag -1 bags to support feeding activities of the test insects that result in weight loss, added protective value differences were only observed when either resistant maize grains $(22 \%$ weight loss) were stored in the Smartbag -1 bags compared to the susceptibe maize ( $28.8 \%$ weight loss). In the laboratory study, the resistant hybrid maize variety (CKPH08028) recorded 25.4\% weight loss under non hermetic conditions (Mwololo et al., 2012). The current work which simulated field conditions demonstrated that no benefits were gained when either resistant or susceptible maize grains were stored in either PICS or SuperGrain II ${ }^{\text {TM }}$ bags. Nevertheless, at 180 days of storage period, CKPH08028 grain stored in PICS bags performed better than SuperGrain II ${ }^{\mathrm{TM}}$ bags. Synergistic benefits in protection were gained when the weight loss of CKPH08028 grains stored in either PICS or SuperGrain II ${ }^{\mathrm{TM}}$ bags were compared to that of the same variety stored in the polypropylene bags. The same maize variety when stored in Smartbag -1 performed poorly compared to either PICS or SuperGrain IITM bags. This could be attributed to the heavy perforation of Smartbag -1 bags by $P$. truncatus and as a result sufficiently low oxygen and high carbon dioxide was not achieved. The novelty of the work is demonstrated in the potential use of hermetic bags in combination with insect resistant maize technologies to significantly reduce weight loss from $30 \%$ to less than $1 \%$ without use of pesticide. This would improve food security at household level. The findings of this study would support agricultural policy formulation and monitoring of loss reduction activities.

\section{Conclusion}

Enriched carbon dioxide environment was not attained in the hermetic bags. Carbon dioxide averaged 5.2\% for both PICS and SuperGrain II ${ }^{\mathrm{TM}}$ bags and $2.6 \%$ of Smartbag -1 bag. PICS and SuperGrain IITM bags maintained low damage and weight loss levels. No grain protection benefits were gained when either insect resistant (CKPH08028) or susceptible (PH5253) maize grains were stored in either PICS or SuperGrain II ${ }^{\mathrm{TM}}$ bags. Synergistic benefits in protection were gained when the weight loss of CKPH08028 grains stored in either PICS or SuperGrain II'M bags were compared to that of the same variety stored in the polypropylene bags. Admixture of maize grain with Actellic super dust and storage in polypropylene bag did not prevent infliction of damage and weight due to insect pests. The study demonstrated the potential in the use of hermetic bags in combination with insect resistant maize technologies to significantly reduce weight loss from $30 \%$ to less than $1 \%$ without use of pesticide.

\section{Acknowledgements}

The study was carried out with the financial support from Swiss Agency for Development Cooperation (SDC) through CIMMYT Effective Grain Storage Project II. Thanks to the Kenya Agricultural and Livestock Research Organisation (KALRO) for providing space for the study at Kiboko. The mention of trade names in this paper is only for the purpose of providing specific information and does not imply endorsement by KALRO, CIMMYT and Kenyatta University. The views expressed in the study are solely the opinion of the authors.

\section{Reference}

[1] ACDI/VOCA-Kenya, 2007. Kenya maize handbook training manual No.27.

[2] ADEBIRE, C.O. and LAJIDE, L., 2003. Ability of extracts of ten tropical plant species to protect maize against infestation by the maize weevil, Sitophilus zeamais during storage. Nigerian Journal of Experimental Biology 4(2), 175 - 179.

[3] ATHANASSIOU, C. G., KAVALliERATOS, N. G., YIATILIS, A. E., VAYIAS, B. J., MAVROTAS, C. S., and TOMANOVIĆ, Ž., 2008. Influence of temperature and humidity on the efficacy of spinosad against four stored grain beetle species. Journal of Insect Science 8: $60-68$.

[4] BAILEY, S.W. and BANKS, H.J., 1980. A review of recent studies of the effects of the controlled atmospheres on stored product pests. In: Shejbal, J. (Eds) Controlled atmosphere storage of grains. International Symposium Proceedings, 12 - 65 May 1980, Castel Gandolfo, Italy, Elsevier, Amsterdam, pp. $101-118$.

[5] BAOUA,I.B., AMADOU, L., OUSMANE, B., BARIBUTSA, D. and MURDOCK, L.L., 2014. PICS bags for postharvest storage of maize grain in West Africa. Journal of Stored Products Research 58, 20 28.

[6] BEAUDRY, R.M., 1999. Effect of O2 and CO2 partial pressure on selected phenomena affecting fruit and vegetable quality. Postharvest Biology and Technology 15,293 - 303 


\section{International Journal of Science and Research (IJSR) \\ ISSN (Online): 2319-7064}

Index Copernicus Value (2013): 6.14 | Impact Factor (2014): 5.611

[7] BOXALL, R.A., 1986. A critical review of the methodology for assessing farm level grain losses after harvest. Tropical Stored Products Paper No. G191.

[8] BRAGA, L.S., CORRÉA, A.S., PEREIRA, E.J.G. and GUEDES, R.N.C., 2011. Face or flee? Fenitrothion resistance and behavioural response in populations of the maize weevil, Siotphilus zeamais. Journal of Stored Product Research 47, 161 - 167.

[9] BROOKS, S., THOMPSON, J., ODAME, H., KIBAARA, B., NDERITU, S., KARIN, F. and MILLSTONE, E., 2009 Environmental Change and Maize Innovation in Kenya: Exploring Pathways In and Out of Maize, STEPS Working Paper 36, Brighton: STEPS Centre

[10] CHEBET, F., DENG, A.L., OGENDO, J.O., KAMAU, A.W. and BETT, P.K., 2013. Bioactivity of selected plant powders against Prostephanus truncatus (Coleoptera: Bostrichidae) in stored maize grains. Plant Protection Science 49(1), 34 - 43.

[11]CHEN, S., ZHANG, M. andWANG, S., 2011. Effect of initial hermetic sealing on quality of 'Kyoho' grapes during storage. Postharvest Biology and Technology 59, $194-199$.

[12] CIMMYT (2013). Kiboko crops research station: A brief and visitor guide.: CIMMYT.

[13]DE GROOTE, H., KIMENJU, S.C., LIKHAYO, P., KANAMPIU, F., TEFERA, T. and HELLIN, J., 2013. Effectiveness of hermetic systems in controlling maize storage pests in Kenya. Journal of Stored Products Research 53, 27 - 36.

[14]DENLOYE, A.A., TESILIM, K.O., NEGBENEBOR, H. and MAKANJUOLA, W.A., 2008. Assessment of the efficacy of Actellic and Sumithion in protecting grains from insect infestation during storage. Journal of Entomology 5: 24 - 30.

[15]DERERA, J., PIXLEY, K.V., GIGA, D.P. AND MAKANDA, I.,2014. Resistance of maize to the maize weevil: III. Grain weight loss assessment and implications for breeding. Journal of Stored Product Research 59, 24 - 35

[16] ENOBAKHARE, D.A. and LAW - OGBOMO, K.E., 2002. Reduction of postharvest loss caused by Sitophilus zeamais (Motsch.) in three varieties of maize treated with plant products. Postharvest Science 1, 1 - 6.

[17]FAO, 2009. Postharvest losses aggravate hunger. Media -Centre - FAO, Rome, Italy.

[18] http//:www.fao.org (accessed 15.01.015)

[19]GIRISH, G.K., 1965. Effects of temperature on the development of stored grain insect pests. Bulletin of Grain Technology 3, 142 - 154

[20] GITONGA, Z.M., DEGROOTE, H., KASSIE, M. and TEFERA, T., 2013. Impact of metal silos on household's maize storage, storage losses and food security: An application of propensity score matching. Food Policy 43, 44 - 55.

[21] HAYMA, J., 2003. The storage of tropical agricultural products, fourth edition, Agromisa Foundation, Wageningen, Netherlands.

[22] HELL, K., OGNAKOSSAN, E.K., TOUNOU, A.K., LAMBONI, Y., ADABE, K.E. and COULIBALY, O., 2010. Maize stored pests control by PICS- bags: technological and economic evaluation. In: Tamò, M.,
Fatokun, C., Boukar, O., Coulibaly, O., Muranaka, S. (Eds), Improving livelihoods in the cowpea value chain through advancements in Science. Proceedings of the $5^{\text {th }}$ World Cowpea Research Conference, 26 September - 1 October 2010, Saly, Senegal.

[23] HODGES, R.J., BUSBY, J.C. and BENNETT, B., 2011. Postharvest losses and waste in developed and less developed countries: opportunities to improve resource use. Journal of Agricultural Science 149, 37 45.

[24] HOWARD, D.C., 1983. The population biology of the greater grain borer Prostephanus truncatus (Horn). Ph.D Thesis, University of Reading.

[25] MCCANN, J. C., DALTON, T. J. and MEKURIA, M., 2006. Breeding for Africa's New Smallholder Maize Paradigm. International Journal of Agricultural Sustainability 4(2), 99-107

[26] MORENO-MARTINÉZ， E., JIMENÉZ, A.S. and VAZQUÉZ, M.E., 2000. Effect of Sitophilus zeamais and Aspergillus Chevalieri on oxygen level in maize stored hermetically. Journal of Stored Product Research $36,25-36$.

[27] MUTAMBUKI, K., NGATIA, C.M. AND MBUGUA, J.N., 2011. Postharvest technology transfer to reduce on -farm grain losses in Kitui District, Kenya. Journal of Agricultural Science and Technology B1: 392 - 399.

[28] MUTUNGI, C.M., AFFOGNON, A., NJORONGE, A.W., BARIBUTSA, D and MURDOCK, L.L., 2014. Storage of mung bean (Vigna radiata [L.] Wilczek) and pigeopea grains (Cajanus cajan [L.] Millsp) in hermetic triple - layer bags stops losses caused by Callosobruchus maculatus (F.) (Coleoptera: Bostrichidae). Journal of Stored Product Research 58, 39 - 47.

[29]MWOLOLO, J.K., MUGO, S., TEFERA, T. and MUNYIRI, S.W., 2013. Evaluation of traits of resistance to Postharvest insect pests in tropical maize. International Journal of Agriculture and Crop Science 6(13) 926 - 933.

[30] MWOLO, J.K., MUGO, S., TEFERA, T., OKORI, P., MUNYIRI, S.W., SEMAGN, K., OTIM, M. and BEYENE, Y., 2012. Resistance of tropical maize genotypes to the larger grain borer. Journal of Pest Science 85(2) 267 - 275.

[31]NGAMO, T.S.L., NGASSOUM, M.B. MAPONGMESTSEM, P.M., HAUBRUGE, E., LOGNAY, G. and HANCE, T., 2007. Current postharvest practices to avoid insect attacks on stored grains in Northern Cameroon. Agriculture Journal 2, $242-247$.

[32] NJOROGE, A.W., AFFOGNON, H.D., MUTUNGI, C.M., MANONO, J., LAMUKA, P.O. and MURDOCK, L.L., 2014. Tripple bag hermetic storage delivers a lethal punch to Prostephanus truncatus (Horn) (Coleoptera: Bostrichidae) in stored maize. Journal of Stored Products Research, doi/10.1016/j.jspr.2014.02.005, p.1 - 8.

[33] OFUYA, T.I., IDOKO, J.E. and AKINTEWE, L.A., 2008. Ability of Sitophilus zeamais Motschulsky (Coleoptera: Curculionidae) from four locations in Nigeria to infest and damage three varieties of maize, Zea mays L. Niger Journal of Entomology 25,34- 39.

\section{Volume 4 Issue 12, December 2015}


[34] OGENDO, J.O., DENG, A.L., BELMAIN, S.R., WALKER, D.J. and MUSANDU, A.A.O., 2004. Effect of insecticidal plant materials, Lantana camara L. and Tephrosia Vogelii Hook, on the quality parameters of stored maize grains. Journal of Food Technology in Africa 9, 29 - 35.

[35]OJO, J.A. and OMOLOYE, A.A., 2012. Rearing the maize weevil, Sitophilus zeamais, on an artificial maize - cassava diet. Journal of Insect Science 12, 1 - 9

[36] PEREÍRA, C.J., PEREÍRA, E.J.G., CORDEIRO, E.M.G., DELLA LUCIA, T.M.C., TÓTOLA, M.R. and GUEDES, R.N.C.,2009. Organophosphate resistance in the maize weevil Sitophilus zeamais: Magnitude and behaviour. Crop Protection 28,168 - 73.

[37]PURSEGLOVE, J.W., 1992. Tropical crops: Monocotyledons. Longman Group, Singapore, pp.607.

[38] SAMSON, P.R., PARKER, J. and JONES, A.L., 1988. Comparative effect of grain moisture on the biological activity of protectants on stored corn. Journal of Economic Entomology 81: 949 - 954.

[39] VASSILAKOS, T.N. and ATHANASSIOU, C.G., 2012. Effect of uneven distribution of Spinetoram treated wheat and rice on mortality and progeny production of Rhyzopertha dominica (F.), Sitophilus oryzae (L.) and Tribolium confusum Jacquelin du Val. Journal of Stored Product Research 50, 73 - 80.

[40] WONG-CORRAL, F.J., RAMIREZ-MARTÍNEZ, M., CORTEZ-ROCHA, M.O., BORBOA- FLORES, J. and LEOS-MARTÍNEZ, J., 2001. Presence of Prostephanus truncatus (Horn) (Coleoptera: Bostrichidae) in Sanora, Mexico, first report. Southwestern Entomologist 26(2), $151-158$.

[41] YIGESU, Y.A., ALEXANDER, C.A., PRECKEL, P.V., MAIR, D.E., MASON, L.J., WOLOSHUK, C., LAWRENCE J. and MOOG, D.J., 2010. Economics of integrated Insect Management in stored corn. Journal of Economic Entomology 103 (5), 1896 - 1908. 